\title{
Celecoxib increases miR-222 while deterring aromatase-expressing breast tumor growth in mice
}

Tsz Yan Wong ${ }^{1+}$, Fengjuan Li ${ }^{2 \dagger}$, Shu-mei Lin ${ }^{5}$, Franky L Chan ${ }^{3}$, Shiuan Chen ${ }^{4}$ and Lai K Leung ${ }^{1,2^{*}}$

\begin{abstract}
Background: Breast cancer is one of the most deadly diseases in women. Inhibiting the synthesis of estrogen is effective in treating patients with estrogen-responsive breast cancer. Previous studies have demonstrated that use of cyclooxygenase (COX) inhibitors is associated with reduced breast cancer risk.

Methods: In the present study, we employed an established mouse model for postmenopausal breast cancer to evaluate the potential mechanisms of the COX-2 inhibitor celecoxib. Aromatase-expressing MCF-7 cells were transplanted into ovariectomized athymic mice. The animals were given celecoxib at 1500 ppm or aspirin at 200 ppm by oral administration with androstenedione injection.

Results: Our results showed that both COX inhibitors could suppress the cancer xenograft growth without changing the plasma estrogen level. Protein expression of ERa, COX-2, Cyclin A, and BCl-xL were reduced in celecoxib-treated tumor samples, whereas only BCl-xL expression was suppressed in those treated with aspirin. Among the breast cancer-related miRNAs, miR-222 expression was elevated in samples treated with celecoxib. Further studies in culture cells verified that the increase in miR-222 expression might contribute to ERa downregulation but not the growth deterrence of cells.
\end{abstract}

Conclusion: Overall, this study suggested that both celecoxib and aspirin could prevent breast cancer growth by regulating proteins in the cell cycle and apoptosis without blocking estrogen synthesis. Besides, celecoxib might affect miR expression in an undesirable fashion.

Keywords: Celecoxib, Aspirin, Aromatase, miRNA

\section{Background}

Cyclooxygenase (COX) or prostaglandin G/H endoperoxide synthase is the enzyme responsible for converting arachidonic acid into prostaglandins [1]. Two isozymes of COX with differential expression patterns have been identified. COX-1 is constitutively expressed, and is involved in normal physiological functions, such as vascular homeostasis, platelet aggregation, gastric mucosa protection and maintenance of renal blood flow [2]. In

\footnotetext{
*Correspondence: laikleung@cuhk.edu.hk

${ }^{\dagger}$ Equal contributors

${ }^{1}$ Food and Nutritional Sciences Programme, School of Life Sciences, Faculty of Science, The Chinese University of Hong Kong, Rm.507C MMW Bldg,

Shatin, Hong Kong

${ }^{2}$ Biochemistry Programme, School of Life Sciences, Faculty of Science, The

Chinese University of Hong Kong, Shatin, Hong Kong

Full list of author information is available at the end of the article
}

contrast, COX-2 expression can be induced by cytokines and growth factors. This implies that COX-2 has a greater involvement in inflammation and cancer development than COX-1 [3]. Studies have shown that COX-2 is expressed in breast cancer tissues but not in normal breast tissues $[4,5]$. The concentrations of prostaglandin $\mathrm{E}_{2}\left(\mathrm{PGE}_{2}\right)$ in tumor and metastatic tissues are also higher than those in normal tissues [6]. The significance of COX-2 in breast carcinogenesis has also been described in different levels of research. Over-expressing COX-2 in mice promotes breast cancer development [7], whereas the administration of COX-2 inhibitor could prevent against breast carcinogenesis [8-10].

Aspirin is a non-steroidal anti-inflammatory drug (NSAID) that inhibits both COX-1 and COX-2. It is capable of deterring the growth of breast cancer cells [11]. 
Regular use of aspirin after breast cancer diagnosis improves survival [12]. In contrast, celecoxib is a new NSAID that specifically inhibits COX-2 and has drawn much attention for its anti-cancer properties. The COX-2 inhibitor reduces mammary tumor incidence induced by DMBA in rats [13]. It is also effective in blocking the growth of breast cancer xenografts in nude mice [14]. Celecoxib could evoke cell cycle arrest, anti-angiogenesis [15], and apoptotic cell death [16,17] in cancers. Although these NSAIDs appear to be chemopreventive, side effects like gastrointestinal tract bleeding [18] and cardiovascular toxicity [19] have been reported.

MicroRNAs (miRNAs) are small noncoding RNAs of about 22 nucleotides (nt) in length, and they can regulate gene expression at the post-transcriptional level. These single-stranded miRNAs bind to the 3 ' untranslated region (3' UTR) of target mRNAs, and cause translation blockage and/or mRNA degradation [20]. Studies have shown that miRNAs may regulate biological processes, like differentiation [21], cell growth and death [21], and tumorigenesis [22,23]. Many miRNAs are under-expressed in human tumors compared to normal tissues [24].

The objective of this study was to determine differential gene expression and other potential growth-suppressing mechanisms in breast tumorigenesis after celecoxib and aspirin treatment. We hypothesized that aromatase activity and miRNA regulation could be differentially inhibited by the two NSAIDs.

\section{Methods}

Celecoxib was a gift from Pfizer Corp. Hong Kong Ltd. Aspirin was obtained from Sigma Chemical Co. (St. Louis, MO). Other chemicals were ordered from Sigma Chemical, if not stated.

\section{Cell culture}

MCF-7 cells stably transfected with human CYP19 (MCF7aro) were prepared as previously described [25]. These cells were maintained in MEM medium (Invitrogen, Grand Island, NY) supplemented with 10\% fetal bovine serum (Invitrogen Life Technology, Rockville, MD) and the selection antibiotic G418 (500 $\mathrm{\mu g} / \mathrm{ml}$, USB, Cleveland, OH). They were incubated at $37^{\circ} \mathrm{C}$ in $5 \%$ carbon dioxide and routinely sub-cultured when reaching $80 \%$ confluency.

\section{Part I. Animal experiment}

This mouse model for postmenopausal breast carcinogenesis was described by Yue et al. [26]. Six-week old female athymic mice were acquired from the Animal Facility of Chinese University of Hong Kong. These mice were ovariectomized and allowed 3 weeks to recover, and were fed purified phytoestrogen-free AIN-93G diet. They were transplanted with MCF-7aro cells and randomly assigned into 4 regimens: control mice (Control), mice injected
Table 1 List of primers designed for RT-PCR quantitation

\begin{tabular}{ccc}
\hline & Forward primer sequence & Reverse primer sequence \\
\hline MYC & 5'-TCT TCC AGA TAT CCT & 5'-TAT GAC CTC GAC TAC GAC \\
& CGC TG-3' & TCG-3' \\
E2F2 & 5'-TTA CAG TCA GAG GCC & 5'-TTC TAA TAC TCA TCC CTG \\
& TGG CT-3' & TTT TTC C-3' \\
GAPDH & 5'-GAG TCA ACG GAT TTG & 5'-GAT CTC GCT CCT GGA AGA \\
& GTC GT-3' & TG-3' \\
\hline
\end{tabular}

with androstenedione (AD), mice injected with androstenedione and treated with celecoxib (AD + celecoxib) and mice injected with androstenedione and treated with aspirin ( $\mathrm{AD}+$ aspirin). The $\mathrm{AD}, \mathrm{AD}+$ celecoxib and $\mathrm{AD}+$ aspirin mice received daily s.c. injections of

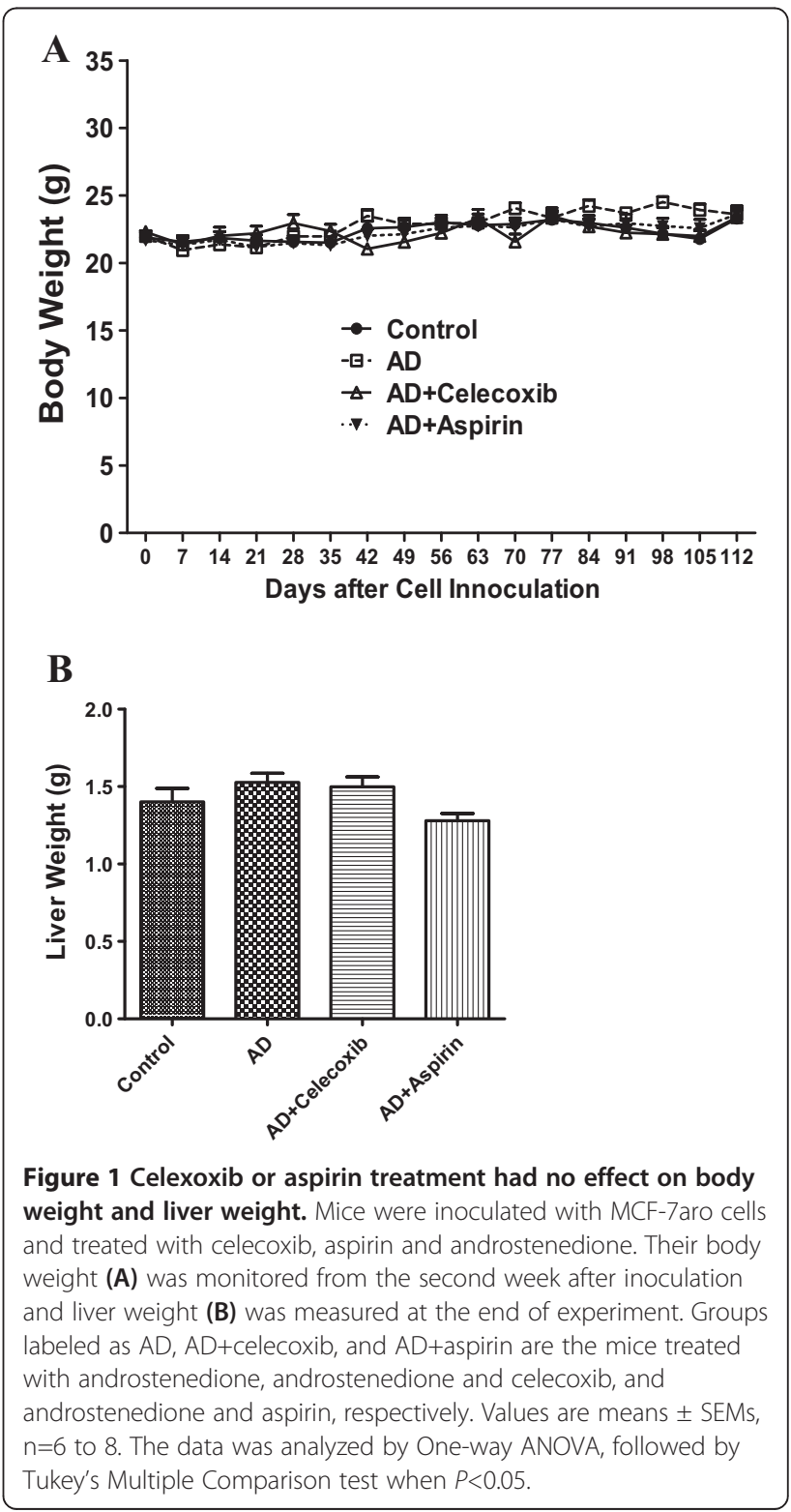




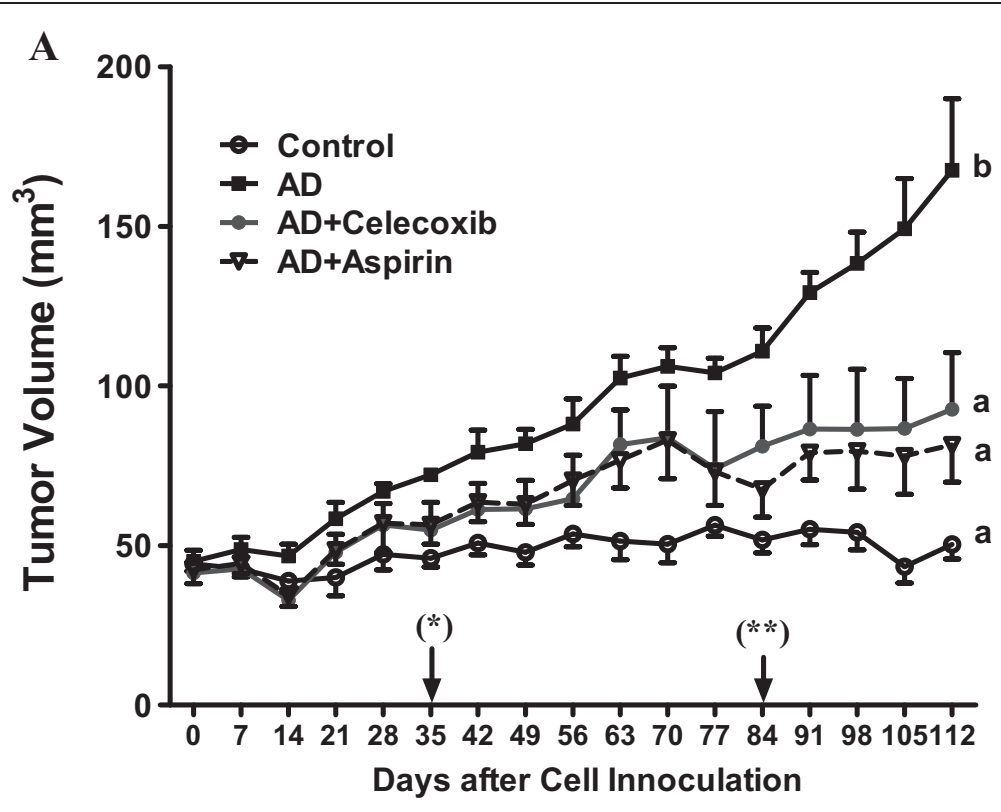

B

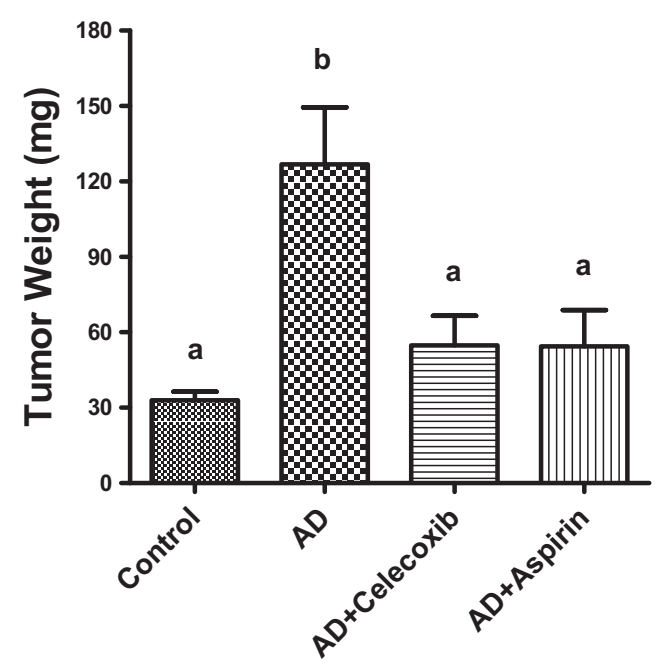

Figure 2 Effect of celecoxib and aspirin on the growth of MCF-7aro xenograft. Mice were inoculated with MCF-7aro cells at 2 sites per mouse after ovariectomy. They were injected subcutaneously with androstenedione every day starting on the next day after inoculation. Tumor volumes (A) were estimated once a week from Day 7 after inoculation. Day labeled as $\left(^{*}\right)$ was the time when AD Group significantly deviated from Control Group sacrifice. $\left(^{*}\right)$ was the day when tumor volumes of AD+Celecoxib and AD+Aspirin started deviated from that of AD. The tumor weight was measured at the day of sacrifice (B). Groups labeled as AD, AD+celecoxib, and AD+aspirin are the mice treated with androstenedione, androstenedione and celecoxib, and androstenedione and aspirin, respectively. Values are means \pm SEM, n=6 to 8 ( 2 inoculation sites combined as one data point). The data was analyzed by One-way ANOVA, followed by Tukey's Multiple Comparison test when $P<0.05$. Means labeled with different letters are significantly different (order: $b>a$ ).

androstenedione (0.1 $\mathrm{mg}$ dissolved in $0.1 \mathrm{ml} 0.3 \%$ hydroxyl propyl cellulose). Control mice received the carrier solvent injection only. Celecoxib and aspirin were administered in the diet at $1500 \mathrm{ppm}$ and $200 \mathrm{ppm}$, respectively. Before transplantation, MCF-7aro cells were maintained in a culture incubator as described above. The cells were trypsinized and suspended in matrigel matrix (BD Biosciences,
San Jose CA) $(10 \mathrm{mg} / \mathrm{ml})$ at $3 \times 10^{7}$ cells $/ \mathrm{ml}$. One hundred $\mu \mathrm{l}$ of cells were injected into the two flanks of the animal. This experiment was approved by Department of Health, the Governemnt of the Hong Kong SAR (Ref (07-164) in $\mathrm{DH} / \mathrm{ORHI} / 8 / 2 / 1$ pt.9), and Animal Experimentation Ethics Committee of the Chinese University of Hong Kong (Ref. 13/023/GRF). 


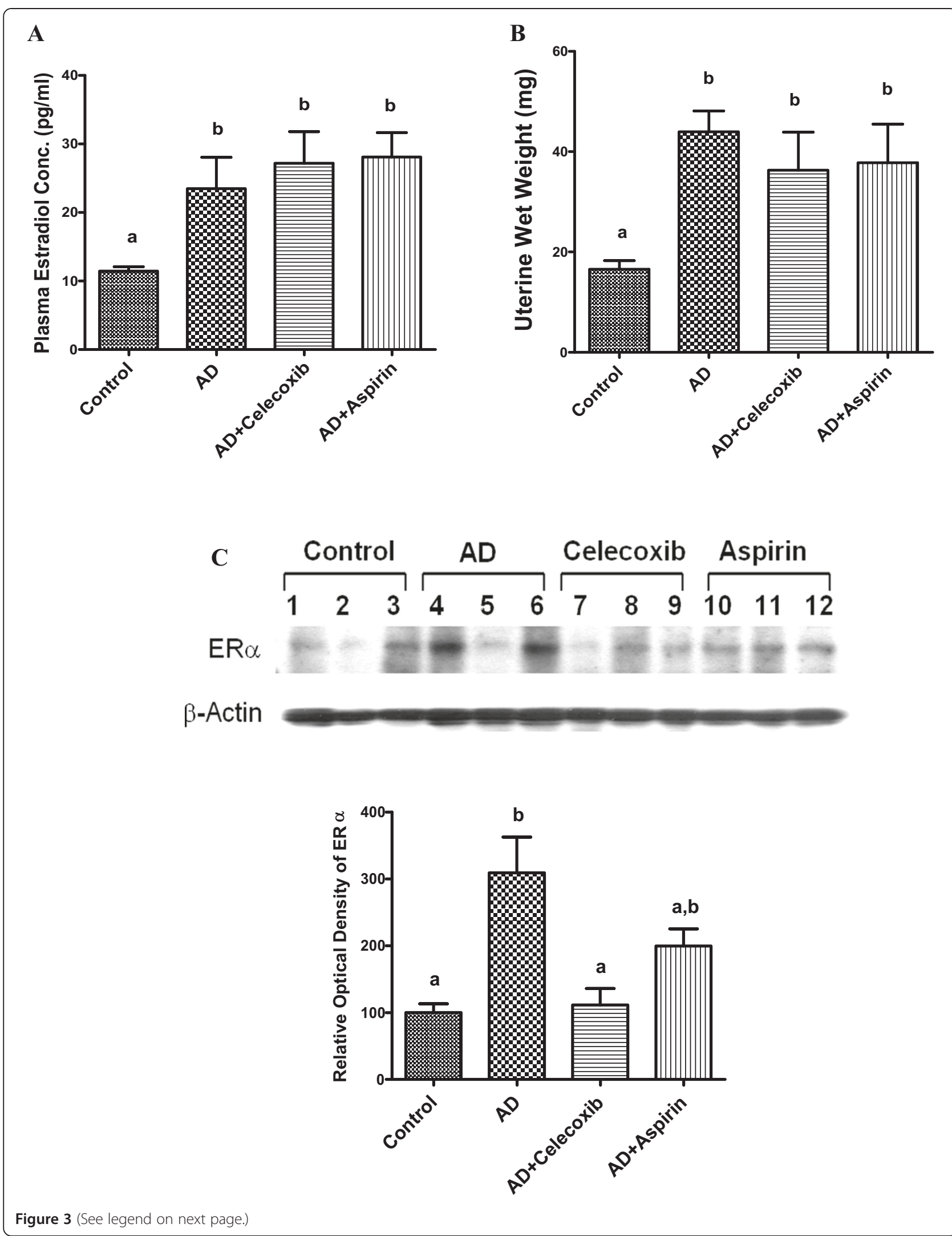


(See figure on previous page.)

Figure 3 Effect of celecoxib and aspirin on plasma estradiol concentration, uterine weight and ERa expression. Blood was drawn from the animals at sacrifice. Serum estradiol concentration was quantified by ELISA (A). Sample labeled as AD is androstenedione. Uterine of the experimental animals were dissected and weighed at sacrifice as shown in $\mathbf{B}$. Western blot analysis of ERa in xenograft samples was analyzed by immunoblotting $\mathbf{( C )}$ and the optical density measurements were shown in the lower panel. Groups labeled as AD, AD+celecoxib, and AD+aspirin are the mice treated with androstenedione, androstenedione and celecoxib, and androstenedione and aspirin, respectively. Values are means \pm SEM, $\mathrm{n}=6$ to 8 .The data was analyzed by One-way ANOVA, followed by Tukey's Multiple Comparison test when $P<0.05$. Means labeled with different letter are significantly different (order: $b>a)$.

The body weight, tumor size and food intake were monitored weekly throughout the study. Tumor volumes were measured by an electronic caliper and estimated according to the formula: $\pi / 6 \times$ length $\times$ width $\times$ height, where length, width, and height were the three orthogonal diameters of the tumors. At the end of the study, the mice were euthanized by cervical dislocation. Livers and uteri were weighed. Tumors and serum were collected and stored at $-80^{\circ} \mathrm{C}$ until assayed.

\section{Quantitative real time PCR assay}

The frozen tumor samples were pulverized in a Dounce homogenizer with liquid nitrogen. Total RNA was extracted from the sample using TRIzol reagent (Invitrogen, Carlsbad, CA, USA). The concentration and purity of RNA were determined by absorbance measured at 260/280 nm. First DNA strands were synthesized from $3 \mu \mathrm{g}$ total RNA using $5 \times$ primers (Assay-on-Demand ${ }^{\mathrm{Tm}}$, Applied Biosystems, Foster City, CA, USA) and MMLV reverse transcriptase (USB Corporation, Cleveland, OH, USA). Target fragments were quantified by DNA Engine Opticon II (MJ Research, Inc., Waltham, MA). Probes for amplification were obtained from Assay-on-Demand ${ }^{\mathrm{Tm}}$, Applied Biosystems, i.e. the housekeeping U6 snRNA (Assay ID: 001973), hasmiR-let-7c (Assay ID: 000379), has-miR-Let-7 g (Assay ID: 002282), has-miR-98 (Assay ID: 000577), has-miR-221 (Assay ID: 000524), has-miR-222 (Assay ID: 002276), has-miR-17-5P (Assay ID: 000393), has-miR-101 (Assay ID: 002253), has-miR-145 (Assay ID: 002278). We used the Real-time PCR Taqman Universal PCR Master Mix (Applied Biosystems) to set up the PCR reactions as described in the manual. Signals obtained from U6 were utilized for normalization, and relative gene expression were analyzed by using the $2^{-\Delta \Delta C T}$ method [27].

For the determination of MYC and E2F2 RNA expression, we used oligo-dT primers for the first strand synthesis, SYBR green PCR Master Mix Reagent kit (Applied Biosystems) for the reaction setup, and GAPDH for normalization. The gene-amplification primer sequences were shown as below. By analyzing the dissociation curves and gel images, these primers did not produce nonspecific amplifications. The relative gene expression was also determined by the $2^{-\Delta \Delta C T}$ method (see Table 1 ).

\section{Immunoblot of proteins extracted from MCF-7aro tumors}

The frozen samples were pulverized in a Dounce homogenizer with added liquid nitrogen. The pulverized samples were then sonicated in lysis buffer (PBS, 1\% NP40, $0.5 \%$ sodium deoxycholate, $0.1 \% \mathrm{SDS}, 40 \mathrm{mg} / \mathrm{L} \mathrm{PMSF}$, $0.5 \mathrm{mg} / \mathrm{L}$ aprotinin, $0.5 \mathrm{mg} / \mathrm{L}$ leupeptin, $1.1 \mathrm{mmol} / \mathrm{L}$ EDTA and $0.7 \mathrm{mg} / \mathrm{L}$ pepstatin) with a cell disruptor (Branson Ultrasonics Corp., Danbury, CT, U.S.A.) on ice for $30 \mathrm{~s}$ for protein extraction. Thirty $\mu \mathrm{g}$ of protein extract were separated on 10\% SDS-PAGE and transferred onto an Immobilon PVDF membrane (Millipore, Bedford, MA). Anti-ER $\alpha$, anti-COX-2, anti-CDK4, Cyclin A, E, anti-Bcl-xL, Bcl-2, Bax, Bak (Santa Cruz Biotechnology, Santa Cruz, CA, USA), and anti- $\beta$-actin primary (Sigma Chem) and secondary antibodies conjugated with horseradish peroxidase (Santa Cruz Biotechnology) were used for protein detection. The targeted proteins were visualized by autoradiography on a Biomax $\left(K_{o d a k}{ }^{\ominus}\right)$ film. The images were scanned and analyzed for optical density by using the computer software ImageJ (National Institute of Mental Health, Bethesda MD, USA).

\section{Serum estradiol determination}

Serum estradiol concentration was measured by using ELISA kits from Cayman Chemical Company (Ann Arbor, MI). The samples were added into a 96-well plate coated with antibody raised against estradiol. After incubating with the tracer and developing at room temperature, the absorbance was quantified using a microplate reader (FluroStar ${ }^{\circ}$, BMG Labtechnologies GmBH, Offenburg, Germany). The amount of estradiol could be read against a standard curve constructed with the hormone provided in the kit.

\section{Part II. In vitro experiments CYP19 enzyme inhibition assay}

Two pmol recombinant aromatase protein (human CYP19 Supersomes ${ }^{\oplus}$, BD Gentest, Woburn, MA) was incubated with celecoxib or aspirin in the substrate-containing assay buffer $\left(25 \mathrm{nM}-\left[1 \mathrm{\beta}^{3} \mathrm{H}(\mathrm{N})\right]\right.$ androst-4-ene-3,17-dione (NET926; Perkin-Elmer Life and Analytical Sciences, Boston, MA), $\left.3 \cdot 3 \mathrm{mM}-\mathrm{MgCl}_{2}, 100 \mathrm{mM}-\mathrm{KH}_{2} \mathrm{PO}_{4}(\mathrm{pH} 7 \cdot 4)\right)$. The reaction was initiated by adding $1.3 \mathrm{mM}-\mathrm{NADPH}$ and incubated at $37^{\circ} \mathrm{C}$ for $15 \mathrm{~min}$. An aliquot of the medium was 


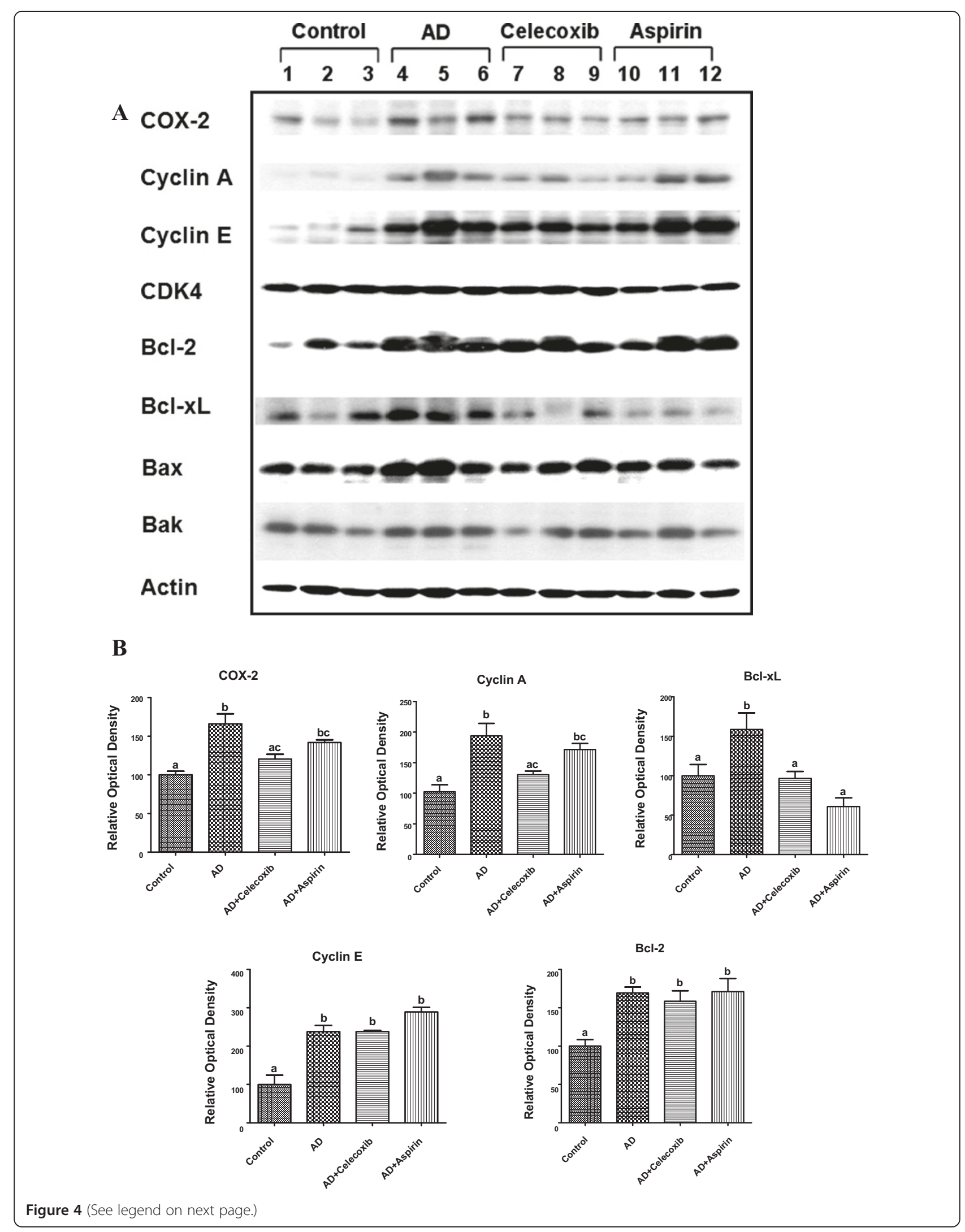


(See figure on previous page.)

Figure 4 Protein expression of COX-2 and genes related to cell cycle and apoptosis. COX-2, cell cycle and apoptosis regulatory proteins were determined by western blot analysis, and the image is shown in $\mathbf{A}$. The corresponding optical density reading is shown in $\mathbf{B}$. Groups labeled as AD, AD+celecoxib, and AD+aspirin are the mice treated with androstenedione, androstenedione and celecoxib, and androstenedione and aspirin, respectively. Values are means $\pm \mathrm{SEM}, \mathrm{n}=3$ to 5 . The data was analyzed by One-way ANOVA, followed by Tukey's Multiple Comparison test when $P<0.05$. Means labeled with different letter are significantly different (order: $b>a$ ).

mixed with chloroform and centrifuged at 10,000 $\mathrm{g}$ for $10 \mathrm{~min}$ at $4^{\circ} \mathrm{C}$. The aqueous phase was transferred into a tube containing $500 \mu \mathrm{l}$ of $5 \%$ activated charcoal. An aliquot of the supernatant was removed for scintillation counting after incubating for $30 \mathrm{~min}$.

\section{Verification of expression pattern in culture cells}

MCF-7aro cells were seeded in culture dishes at $5 \times 10^{2}$ cells $/ \mathrm{mm}^{2}$, and allowed to settle for 1 day before treatment began. They were co-treated with androstenedione and various concentrations of aspirin or celecoxib for 1-3 days with DMSO as the carrier solvent. The final concentration of solvent was $0.1 \%$ ( $\mathrm{vol} / \mathrm{vol})$. Total protein or RNA was extracted and analyzed.

\section{Relationship between the differentially expressed genes and miR-222/-98}

MCF-7aro cells were cultured in OptiMEM (Invitrogen Life Technology) and transfected with miR-222 or miR-98 mimics (Invitogen Life Technology) in Lipofectamine 2000 (Invitrogen Life Technology). Six hr after the transfection, the culture medium was replaced with RPMI (phenol red free) supplemented with $10 \mathrm{nM}$ androstenedione and 5\% charcoal-dextran treated fetal bovine serum (Biotechnics Research, CA USA). Total protein or RNA was extracted $72 \mathrm{hr}$ after the medium change. MTT assays were also performed in separate experiments to investigate the effect on cell growth.

\section{Statistical methods}

The software package Prism ${ }^{\circledR} 5.0$ (GraphPad Software, Inc., CA, USA) was employed for statistical analysis. For multiple group analysis, the data were analyzed by One-way ANOVA followed by Tukey's Multiple Comparison if significant differences $(\mathrm{P}<0.5)$ were observed.

\section{Results}

Celecoxib and aspirin treatment had no effect on mouse body weight and liver weight

The body weights of all mice gradually increased and no significant differences were observed among the groups at any given time point (Figure 1A). Similar to the body weights, no significant differences were observed in liver weights at euthanasia (Figure 1B). The drug treatment appeared to be within the tolerable limit.
Effect of celecoxib and aspirin on xenograft growth

Accelerated tumor growth was recorded in mice treated with androstenedione (AD) as compared with that of Control. Tumor volume in AD mice became significantly $(\mathrm{P}<0.05)$ different from that in Control starting from Day 35 until sacrifice. Beginning from Day 84 until euthanasia, tumor volumes in the treatment groups $\mathrm{AD}+$ celecoxib and $A D+$ aspirin were significantly $(P<0.05)$ smaller than those in $\mathrm{AD}$ mice (Figure $2 \mathrm{~A}$ ). The tumor weights measured at euthanasia were consistent with the tumor volume data (Figure 2B).

\section{Celecoxib decreased ERa expression without affecting plasma estradiol concentration and uterine weight} All mice received androstenedione had higher plasma estradiol concentrations than those in Control mice. No reduction in estradiol was observed in mice treated with celecoxib or aspirin (Figure 3A). AD mice exhibited a twofold increase in uterine wet weight over that of Control. Treatment with celecoxib or aspirin did not significantly change the androstenedione-induced uterine weight (Figure 3B). The uterine weight data were consistent with the plasma estrogen concentrations. The androstenedioneinduced expression of $\mathrm{ER} \alpha$, on the other hand, was reversed by celecoxib administration (Figure 3C).

\section{Expression of COX-2, cell cycle and apoptosis-related proteins in tumors}

Since both celecoxib and aspirin inhibited tumor growth in the animal model, we examined some proteins that are important in regulating cell growth. COX-2, Cyclin A \& E, $\mathrm{Bcl}-2$, and $\mathrm{Bcl}-\mathrm{xL}$ were higher in $\mathrm{AD}$ tumor samples than those in the Control as shown in Figure 4. Both NSAIDs counteracted the androstenedione-induced Bcl-xL, while celecoxib could also neutralize the induced expression of COX-2 and Cyclin A. Other proteins (CDK4, Bax, and Bak) were not different among all treatment groups.

\section{MiRNA expression in tumors}

Expression of breast cancer-associated miRNAs, including miR-let-7c, miR-let-7 g, miR-98, miR-221, miR-222, miR101, miR-145 and miR-17-5p, in the xenografts was also measured. Among these, miR-98 (Figure 5A) and miR-222 (Figure 5B) were downregulated in $\mathrm{AD}$ mice. Aspirin and celecoxib could reverse the suppression of miR-98 and miR-222, respectively. Although the expression of miR-145 was not significantly changed among all groups, celecoxib 
Figure 5 MiRNA expression in tumors in mice treated with celecoxib and aspirin. Total mRNA was extracted from tumors and miRNA expression of miR-98 (A), 222 (B), 145 (C) was quantified by real-time PCR. Groups labeled as $A D, A D+$ celecoxib, and $A D+$ aspirin are the mice treated with androstenedione, androstenedione and celecoxib, and androstenedione and aspirin, respectively. Values are means \pm SEM, $n=6$. The data was analyzed by One-way ANOVA, followed by Tukey's Multiple Comparison test when $P<0.05$. Means labeled with different letters are significantly different (order: $a>b$ ).

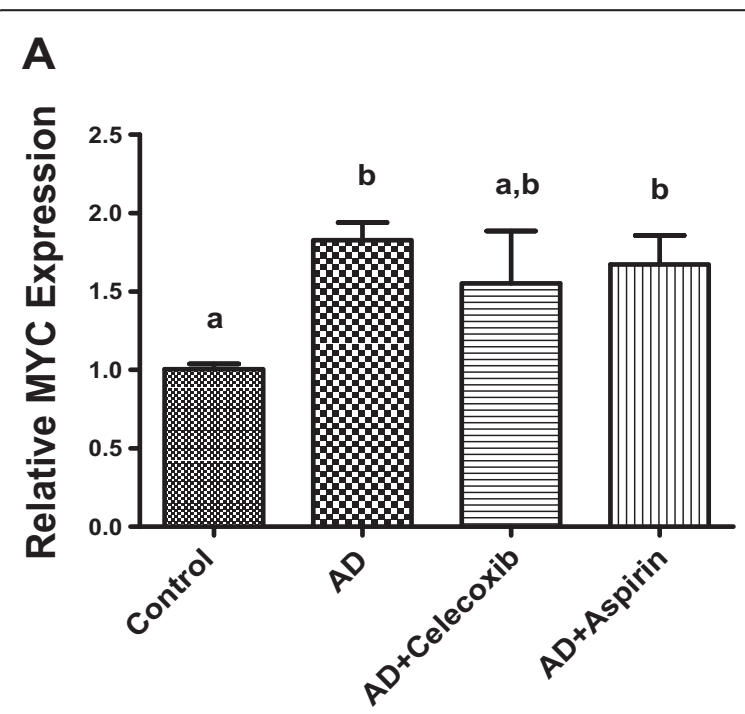

B

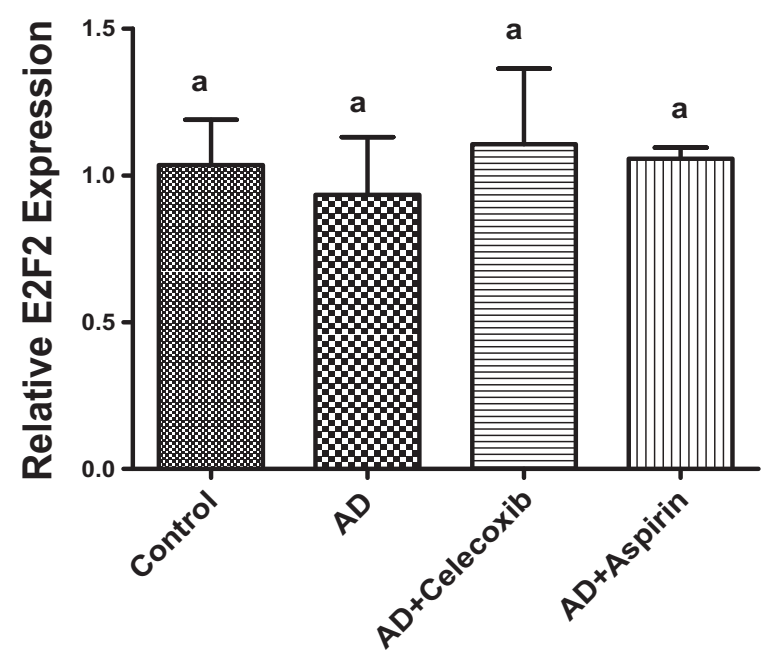

Figure 6 The effect of drug treatment on c-Myc and E2F2 in tumors. Total mRNA was extracted from tumors and mRNA expression level of C-Myc (A) and E2F2 (B) was quantified by real-time PCR. Groups labeled as AD, AD+celecoxib, and AD+aspirin are the mice treated with androstenedione, androstenedione and celecoxib, and androstenedione and aspirin, respectively. Values are means $\pm \mathrm{SEM}, \mathrm{n}=6$.The data was analyzed by One-way ANOVA, followed by Tukey's Multiple Comparison test when $P<0.05$. Means labeled with different letter are significantly different (order: $b>a$ ). 
tended to increase its level (Figure 5C). No significant changes were found in the expression of the other miRNAs (data not shown).

\section{MYC and E2F2 mRNA expression in tumors}

A recent study has documented that MYC and E2F2 can be regulated by miR-98 [28]. The mRNA expression of MYC and E2F2 was examined as a follow-up study to the differential expression of miR-98 as shown above. Our results showed that the mRNA expression of MYC could be induced by androstenedione, but celecoxib and aspirin treatment had no counteracting effect on the expression (Figure 6A). No differences were found in the mRNA expression of E2F2 (Figure 6B).

\section{Celecoxib and aspirin were not aromatase inhibitors}

Celecoxib $(1-10 \mu \mathrm{M})$ and aspirin $(1-1000 \mu \mathrm{M})$ had no inhibition on the aromatase activity of CYP19 recombinant protein (data not shown). These results were consistent with the null effect on plasma estrogen in mice.

\section{Verification of protein expression in the cell culture system}

Immunoblot results indicated that $10 \mathrm{nM}$ androstenedione elevated the protein levels of Bcl-xL, Cyclin A, and Cox-2 and suppressed that of ER $\alpha$. Celecoxib further suppressed ER $\alpha$, and reduced the steroid-induced Bcl-xL, Cyclin A, and Cox-2 levels in the cultured MCF-7aro cells in a dose-dependent manner (Figure $7 \mathrm{~B}$ ). In contrast, aspirin did not affect any of those proteins in the culture system (Figure 7A). The results for celecoxib were consistent to those in the animal study.

\section{MiR-222 expression was induced by celecoxib in MCF- 7aro cells in vitro}

By using real-time PCR assay, we determined the expression of miR-222/-98 in cells treated with celecoxib and aspirin. Compared to the control, androgen administration suppressed the expression of miR-222 and miR-98. Ten $\mu \mathrm{M}$ celecoxib significantly $(\mathrm{P}<0.05)$ reversed the suppression of miR-222 (Figure 8A), whereas no significant changes were observed for miR-98 (Figure $8 \mathrm{C}$ ) or those cultures treated with aspirin (Figure 8B \& D).

\section{MiR-222 could be a factor for ERa suppression}

In order to investigate the connection between miR222/-98 and the protein expression profile, MCF-7aro cells were transfected with mimic miR-222 and miR-98. Androstenedione could reduce ER $\alpha$. The miR-222 mimic further lowered the ER $\alpha$ protein, while other proteins tested were not affected. MiR-98 had no effect on any of the proteins (Figure 9). The administration of miR-222

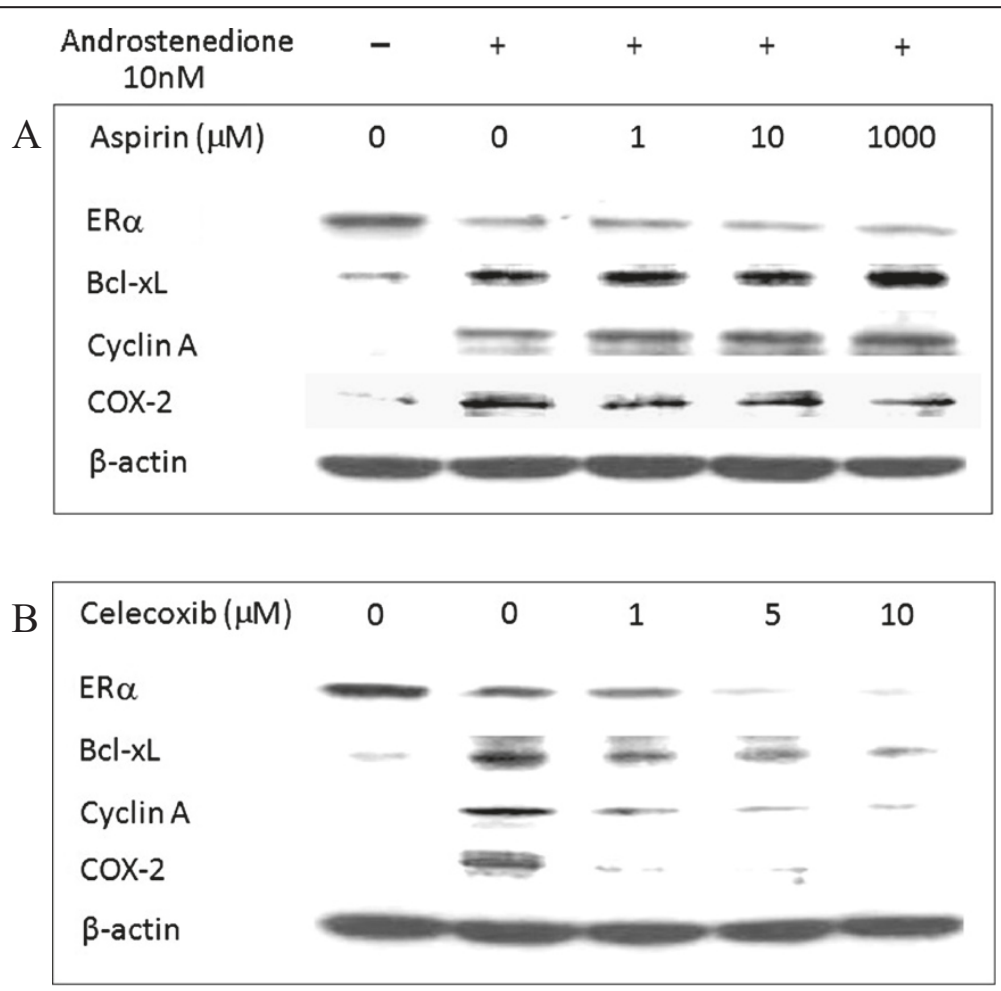

Figure 7 Verification of protein expression in the cell culture system. Western blot analysis was performed on a cell culture system. MCF-7aro cells were cultured and treated with $10 \mathrm{nM}$ androstenedione and aspirin or celecoxib for $72 \mathrm{hr}$. Protein was extracted from the cells. The upper panel (A) is the image for aspirin-treated samples and celecoxib-treated samples are shown in the lower panel (B). 


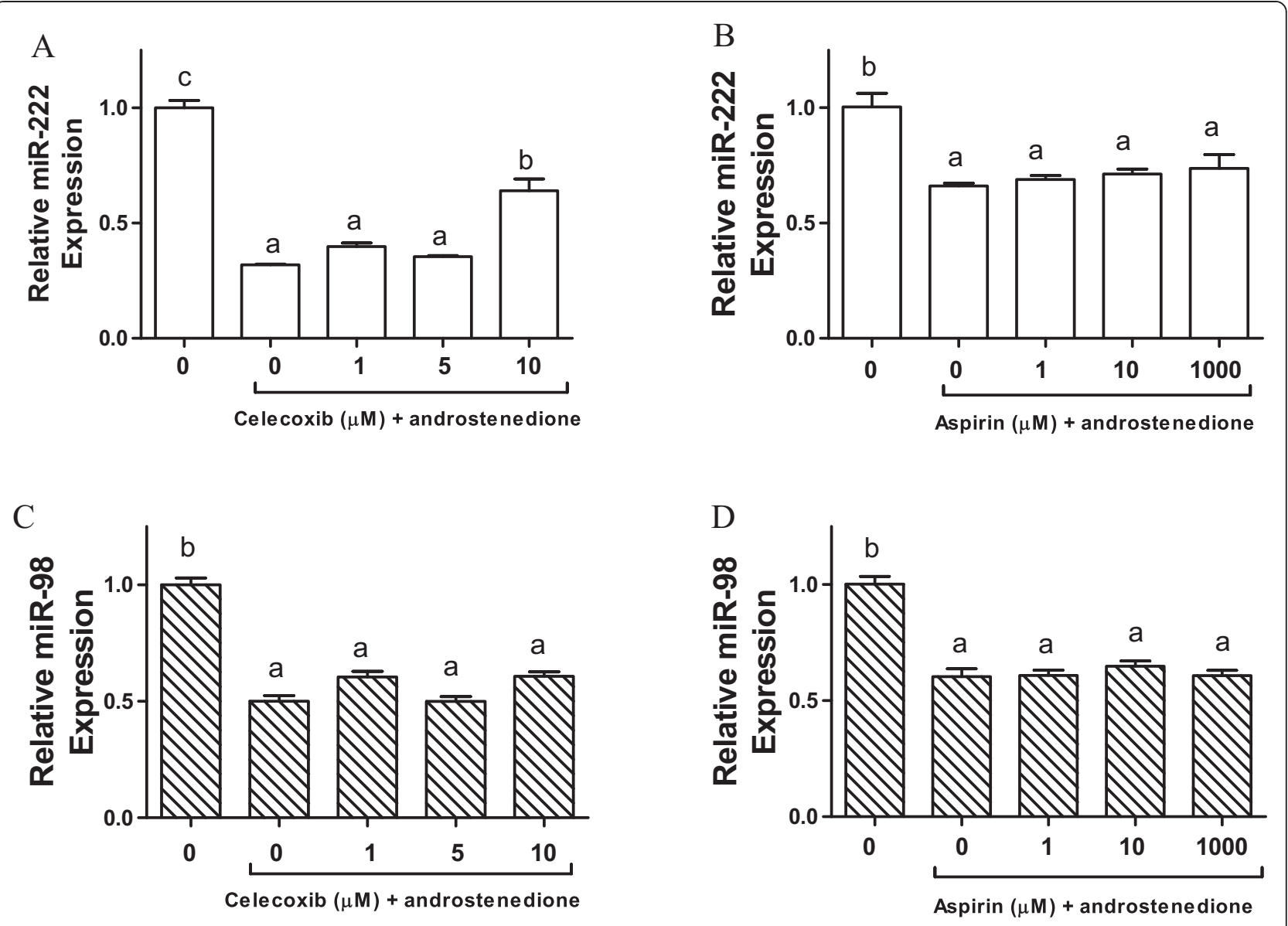

Figure 8 MiR-98 and miR-222 expression in MCF-7aro cells treated with aspirin and celecoxib. Cells are treated with androstenedione and celecoxib, and androstenedione and aspirin. Total mRNA was extracted from cells and miRNA expression of miR-98 and 222 was quantified by real-time PCR. MiR-222 expression of celecoxib and aspirin are shown in $\mathbf{A} \& \mathbf{B}$, while $\mathbf{C} \& \mathbf{D}$ are the miR-98 expression of celecoxib and aspirin, respectively. Values are means $\pm S E M, n=3$. The data was analyzed by One-way ANOVA, followed by Tukey's Multiple Comparison test when $P<0.05$. Means labeled with different letters are significantly different (order: $c>b>a$ ).

inhibitor did not change ER $\alpha$ expression compared with that of miR-222 inhibitor -ve control. The low baseline level of miR-222 could be the contributing factor. MTT assays were also performed in these cultures. No significant difference in cell growth was observed in cells transfected with miR-222 or -98 mimic after 72 -h incubation (data not shown).

\section{Discussion}

Previous studies have demonstrated that celecoxib at high concentrations can suppress aromatase activity [29] and reduce estradiol amount [30] in the cultured breast cancer cells SK-BR-3 and MCF-7/Cox-2 clone. In the present study, we could not validate the celecoxib's inhibition on aromatase activity or expression in MCF-7 cells as high as $10 \mu \mathrm{M}$ (data not shown). Furthermore, the Cox-2 inhibitor was also not effective in lowering estradiol concentration in an aromatase-expressing breast xenograft model. After all, neither celecoxib nor aspirin were suppressors to aromatase at any levels.

Overexpression of cyclins has been observed in breast cancer [31-33]. In contrast, celecoxib and aspirin inhibit cell cycle progression through G1 phase arrest in colon cancer cells $[34,35]$. In the present study, celecoxib but not aspirin reduced the protein levels of Cyclin A. Since the cyclin suppression is consistent with the condition required for G-1 phase arrest, the COX-2 inhibitor might block the cells from entering the $\mathrm{S}$ phase.

Apoptosis is a crucial process in the treatment of cancer. COX-2 promotes resistance against apoptosis by altering the levels of pro- and anti-apoptotic proteins [36,37]. Celecoxib induces apoptosis in breast cancer cells by differential regulation of $\mathrm{Bcl}-2$ and $\mathrm{Bax}$ [38]. Aspirin is also able to induce apoptosis by down-regulating $\mathrm{Bcl}-2$ protein expression in colon cancer cells and human gastric epithelial cells $[39,40]$. Rather than reducing Bcl-2, both celecoxib and aspirin decreased $\mathrm{Bcl}-\mathrm{xL}$ in the present study. 


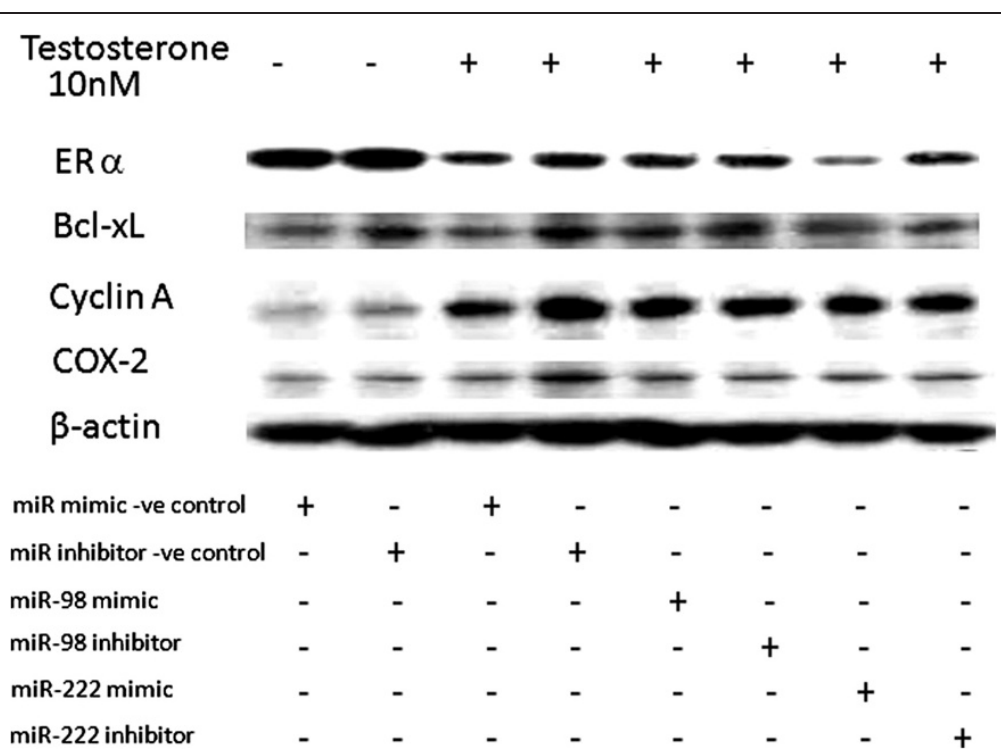

Figure 9 Protein expression in miR-98 and miR-222 over-expressed MCF-7aro cells. Cells are treated with androstenedione and transfected with miR-98 or miR-222. Protein was extracted from cells and expression of ERa, Bcl-xL, Cyclin A, and Cox-2 was quantified by western blot. The image represents one of two blots with similar results.

Dysregulation of miRNAs has been demonstrated in breast carcinogenesis, and their involvement in cancer initiation and progression has been suggested [41,42]. MiR-98 may interact with and reduce the expression of CYP19 [43], c-Myc and E2F2 [28] in cells. Increased miR-222 species is associated with drug resistance and estrogenindependent growth [44]. MiR-145, on the other hand, is a tumor suppressor gene and is down-regulated in MCF-7 cells [45]. Over-expressing miR-145 in breast cancer cells suppresses the cell growth and induces apoptosis through downregulating ER $\alpha$ and Rhotekin expression [46,47]. In addition, miR-145 may also block the expression of Fli-1 and Bcl-2 in colon cancer cells [48]. Our study indicated that androstenedione suppressed $\mathrm{miR}-98$ and -222 , and aspirin and celecoxib reversed the expression in the tumors, respectively. The null result of miR-98 expression in cultures after aspirin treatment was inconsistent with the animal study data. Aspirin could act indirect in controlling miR-98. On the other hand, miR-222 was consistently upregulated by celecoxib administration in both in vivo and in vitro systems. The interrelationship between miR-222 and ER $\alpha$ in the current study was not determined. The induction of miR-222 expression might reduce ER $\alpha$ expression [49], or it could also be a direct result from downregulation of ER $\alpha$ [50].

\section{Conclusion}

In summary, both COX inhibitors suppressed breast tumor growth. However, celecoxib might also upregulate the undesirable miR-222.
Competing interests

The authors declare that no competing interests.

\section{Authors' contributions}

FL mostly performed the in vivo experiments, while TYW performed most in vitro experiments. SL participated in both in vivo and in vitro experiments of this study. FL \& TYW also performed the statistical analysis. FC \& SC constructed the transfection plasmid and prepared the stable cell line MCF-7aro. LKL designed and co-ordinated this study, and drafted the manuscript. All authors read and approved the final manuscript.

\section{Acknowledgements}

The authors would like to thank Pfizer Corp. for providing celecoxib for this study. The authors also wish to express their gratitude to Prof. Howard Glauert of the Graduate Center for Nutritional Sciences at the University of Kentucky for proofreading this manuscript. This project was supported by The Chinese University of Hong Kong Direct Research Grant No. 4053047. TY Wong and F Li were on postgraduate studentships administered by the Graduate School, The Chinese University of Hong Kong.

\section{Author details}

${ }^{1}$ Food and Nutritional Sciences Programme, School of Life Sciences, Faculty of Science, The Chinese University of Hong Kong, Rm.507C MMW Bldg, Shatin, Hong Kong. ${ }^{2}$ Biochemistry Programme, School of Life Sciences, Faculty of Science, The Chinese University of Hong Kong, Shatin, Hong Kong. ${ }^{3}$ School of Biomedical Sciences, Faculty of Medicine, The Chinese University of Hong Kong, Shatin, Hong Kong. ${ }^{4}$ Division of Immunology, Beckman Research Institute of the City of Hope, Duarte, CA 91010, USA. ${ }^{5}$ Department of Food Science, National Chiayi University, Chiayi City, Taiwan.

Received: 6 January 2014 Accepted: 6 June 2014 Published: 12 June 2014

\section{References}

1. Smith WL, DeWitt DL, Garavito RM: Cyclooxygenases: structural, cellular, and molecular biology. Annu Rev Biochem 2000, 69:145-182.

2. Parente L, Perretti M: Advances in the pathophysiology of constitutive and inducible cyclooxygenases: two enzymes in the spotlight. Biochem Pharmacol 2003, 65(2):153-159.

3. Vane JR, Bakhle YS, Botting RM: Cyclooxygenases 1 and 2. Annu Rev Pharmacol Toxicol 1998, 38:97-120. 
4. Brueggemeier RW, Quinn AL, Parrett ML, Joarder FS, Harris RE, Robertson FM: Correlation of aromatase and cyclooxygenase gene expression in human breast cancer specimens. Cancer Lett 1999, 140(1-2):27-35.

5. Badawi AF, Badr MZ: Expression of cyclooxygenase-2 and peroxisome proliferator-activated receptor-gamma and levels of prostaglandin E2 and 15-deoxy-delta12,14-prostaglandin $\mathrm{J} 2$ in human breast cancer and metastasis. Int J Cancer 2003, 103(1):84-90.

6. Rolland PH, Martin PM, Jacquemier J, Rolland AM, Toga M: Prostaglandin in human breast cancer: evidence suggesting that an elevated prostaglandin production is a marker of high metastatic potential for neoplastic cells. J Natl Cancer Inst 1980, 64(5):1061-1070.

7. Liu CH, Chang SH, Narko K, Trifan OC, Wu MT, Smith E, Haudenschild C, Lane TF, Hla T: Overexpression of cyclooxygenase-2 is sufficient to induce tumorigenesis in transgenic mice. J Biol Chem 2001, 276(21):18563-18569.

8. Subbaramaiah K, Zakim D, Weksler BB, Dannenberg AJ: Inhibition of cyclooxygenase: a novel approach to cancer prevention. Proc Soc Exp Biol Med 1997, 216(2):201-210.

9. Taketo MM: Cyclooxygenase-2 inhibitors in tumorigenesis (part I). J Natl Cancer Inst 1998, 90(20):1529-1536.

10. Taketo MM: Cyclooxygenase-2 inhibitors in tumorigenesis (Part II) J Natl Cancer Inst 1998, 90(21):1609-1620.

11. Sotiriou C, Lacroix M, Lagneaux L, Berchem G, Body JJ: The aspirin metabolite salicylate inhibits breast cancer cells growth and their synthesis of the osteolytic cytokines interleukins- 6 and -11 . Anticancer Res 1999, 19(4B):2997-3006.

12. Holmes MD, Chen WY, Li L, Hertzmark E, Spiegelman D, Hankinson SE: Aspirin intake and survival after breast cancer. J Clin Oncol 2010, 28(9):1467-1472

13. Alshafie GA, Abou-Issa HM, Seibert K, Harris RE: Chemotherapeutic evaluation of Celecoxib, a cyclooxygenase- 2 inhibitor, in a rat mammary tumor model. Oncol Rep 2000, 7(6):1377-1381.

14. Blumenthal RD, Waskewich C, Goldenberg DM, Lew W, Flefleh C, Burton J: Chronotherapy and chronotoxicity of the cyclooxygenase-2 inhibitor, celecoxib, in athymic mice bearing human breast cancer xenografts. Clin Cancer Res 2001, 7(10):3178-3185.

15. Grosch S, Maier TJ, Schiffmann S, Geisslinger G: Cyclooxygenase-2 (COX-2)independent anticarcinogenic effects of selective COX-2 inhibitors. J Natl Cancer Inst 2006, 98(11):736-747.

16. Jendrossek V, Handrick R, Belka C: Celecoxib activates a novel mitochondrial apoptosis signaling pathway. FASEB J 2003, 17(11):1547-1549.

17. Leahy KM, Ornberg RL, Wang Y, Zweifel BS, Koki AT, Masferrer JL: Cyclooxygenase-2 inhibition by celecoxib reduces proliferation and induces apoptosis in angiogenic endothelial cells in vivo. Cancer Res 2002, 62(3):625-631.

18. Scheiman JM: Prevention of damage induced by aspirin in the GI tract. Best Pract Res Clin Gastroenterol 2012, 26(2):153-162.

19. Garcia Rodriguez LA, Cea-Soriano L, Tacconelli S, Patrignani P: Coxibs: pharmacology, toxicity and efficacy in cancer clinical trials. Recent Results Cancer Res 2013, 191:67-93.

20. He L, Hannon GJ: MicroRNAs: small RNAs with a big role in gene regulation. Nat Rev Genet 2004, 5(7):522-531.

21. Miska EA: How microRNAs control cell division, differentiation and death. Curr Opin Genet Dev 2005, 15(5):563-568.

22. Kumar MS, Lu J, Mercer KL, Golub TR, Jacks T: Impaired microRNA processing enhances cellular transformation and tumorigenesis. Nat Genet 2007, 39(5):673-677.

23. Voorhoeve PM, le Sage C, Schrier M, Gillis AJ, Stoop H, Nagel R, Liu YP, van Duijse J, Drost J, Griekspoor A, Zlotorynski E, Yabuta N, De Vita G, Nojima H, Looijenga LH, Agami R: A genetic screen implicates miRNA-372 and miRNA-373 as oncogenes in testicular germ cell tumors. Cell 2006, 124(6):1169-1181.

24. Lu J, Getz G, Miska EA, Alvarez-Saavedra E, Lamb J, Peck D, Sweet-Cordero A, Ebert BL, Mak RH, Ferrando AA, Downing JR, Jacks T, Horvitz HR, Golub TR: MicroRNA expression profiles classify human cancers. Nature 2005, 435(7043):834-838.

25. Zhou DJ, Pompon D, Chen SA: Stable expression of human aromatase complementary DNA in mammalian cells: a useful system for aromatase inhibitor screening. Cancer Res 1990, 50(21):6949-6954.

26. Yue W, Zhou DJ, Chen SA, Brodie A: A New nude-mouse model for postmenopausal breast-cancer using Mcf-7 cells Transfected with the human aromatase gene. Cancer Res 1994, 54(19):5092-5095.
27. Livak KJ, Schmittgen TD: Analysis of relative gene expression data using real-time quantitative PCR and the 2(-Delta Delta C(T)) Method. Methods 2001, 25(4):402-408.

28. Bhat-Nakshatri P, Wang G, Collins NR, Thomson MJ, Geistlinger TR, Carroll JS, Brown M, Hammond S, Srour EF, Liu Y, Nakshatri H: Estradiol-regulated microRNAs control estradiol response in breast cancer cells. Nucleic Acids Res 2009, 37(14):4850-4861

29. Diaz-Cruz ES, Shapiro CL, Brueggemeier RW: Cyclooxygenase inhibitors suppress aromatase expression and activity in breast cancer cells. J Clin Endocrinol Metab 2005, 90(5):2563-2570.

30. Prosperi JR, Robertson FM: Cyclooxygenase-2 directly regulates gene expression of P450 Cyp19 aromatase promoter regions pll, pl.3 and pl.7 and estradiol production in human breast tumor cells. Prostaglandins Other Lipid Mediat 2006, 81(1-2):55-70.

31. Keyomarsi K, Pardee AB: Redundant cyclin overexpression and gene amplification in breast cancer cells. Proc Natl Acad Sci U S A 1993, 90(3):1112-1116.

32. Keyomarsi K, Oleary N, Molnar G, Lees E, Fingert HJ, Pardee AB: Cyclin-E, a potential prognostic marker for breast-cancer. Cancer Res 1994, 54(2):380-385

33. Husdal A, Bukholm G, Bukholm IRK: The prognostic value and overexpression of cyclin $A$ is correlated with gene amplification of both cyclin A and cyclin E in breast cancer patient. Cell Oncol 2006, 28(3):107-116

34. Grosch S, Tegeder I, Niederberger E, Brautigam L, Geisslinger G: COX-2 independent induction of cell cycle arrest and apoptosis in colon cancer cells by the selective COX-2 inhibitor celecoxib. FASEB J 2001, 15(14):2742-2744.

35. Luciani MG, Campregher C, Gasche C: Aspirin blocks proliferation in colon cells by inducing a G1 arrest and apoptosis through activation of the checkpoint kinase ATM. Carcinogenesis 2007, 28(10):2207-2217.

36. Lin MT, Lee RC, Yang PC, Ho FM, Kuo ML: Cyclooxygenase-2 inducing Mcl-1-dependent survival mechanism in human lung adenocarcinoma CL1.0 cells. Involvement of phosphatidylinositol 3-kinase/Akt pathway. J Biol Chem 2001, 276(52):48997-49002.

37. Komatsu K, Buchanan FG, Katkuri S, Morrow JD, Inoue H, Otaka M, Watanabe S, DuBois RN: Oncogenic potential of MEK1 in rat intestinal epithelial cells is mediated via cyclooxygenase-2. Gastroenterology 2005, 129(2):577-590.

38. Basu GD, Pathangey LB, Tinder TL, Lagioia M, Gendler SJ, Mukherjee P. Cyclooxygenase-2 inhibitor induces apoptosis in breast cancer cells in an in vivo model of spontaneous metastatic breast cancer. Mol Cancer Res 2004, 2(11):632-642.

39. Yu HG, Huang JA, Yang YN, Huang H, Luo HS, Yu JP, Meier JJ, Schrader H, Bastian A, Schmidt WE, Schmitz F: The effects of acetylsalicylic acid on proliferation, apoptosis, and invasion of cyclooxygenase-2 negative colon cancer cells. Eur J Clin Invest 2002, 32(11):838-846.

40. Redlak MJ, Power JJ, Miller TA: Role of mitochondria in aspirin-induced apoptosis in human gastric epithelial cells. Am J Physiol Gastrointest Liver Physiol 2005, 289(4):G731-G738

41. Iorio MV, Ferracin M, Liu CG, Veronese A, Spizzo R, Sabbioni S, Magri E, Pedriali M, Fabbri M, Campiglio M, Ménard S, Palazzo JP, Rosenberg A, Musiani P, Volinia S, Nenci I, Calin GA, Querzoli P, Negrini M, Croce CM: MicroRNA gene expression deregulation in human breast cancer. Cancer Res 2005, 65(16):7065-7070.

42. Tavazoie SF, Alarcon C, Oskarsson T, Padua D, Wang Q, Bos PD, Gerald WL, Massague J: Endogenous human microRNAs that suppress breast cancer metastasis. Nature 2008, 451(7175):147-152.

43. Panda H, Chuang TD, Luo $X$, Chegini N: Endometrial miR-181a and miR-98 expression is altered during transition from normal into cancerous state and target PGR, PGRMC1, CYP19A1, DDX3X, and TIMP3. J Clin Endocrinol Metab 2012, 97(7):E1316-E1326.

44. Rao X, Di Leva G, Li M, Fang F, Devlin C, Hartman-Frey C, Burow ME, Ivan M, Croce CM, Nephew KP: MicroRNA-221/222 confers breast cancer fulvestrant resistance by regulating multiple signaling pathways. Oncogene 2011, 30(9):1082-1097.

45. Kent OA, Mendell JT: A small piece in the cancer puzzle: microRNAs as tumor suppressors and oncogenes. Oncogene 2006, 25(46):6188-6196.

46. Spizzo R, Nicoloso MS, Lupini L, Lu Y, Fogarty J, Rossi S, Zagatti B, Fabbri M, Veronese A, Liu X, Davuluri R, Croce CM, Mills G, Negrini M, Calin GA: miR145 participates with TP53 in a death-promoting regulatory loop and 
targets estrogen receptor-alpha in human breast cancer cells. Cell Death Differ 2010, 17(2):246-254.

47. Wang S, Bian C, Yang Z, Bo Y, Li J, Zeng L, Zhou H, Zhao RC: miR-145 inhibits breast cancer cell growth through RTKN. Int J Oncol 2009, 34(5):1461-1466

48. Zhang J, Guo H, Zhang H, Wang H, Qian G, Fan X, Hoffman AR, Hu JF, Ge S: Putative tumor suppressor miR-145 inhibits colon cancer cell growth by targeting oncogene Friend leukemia virus integration 1 gene.

Cancer 2011, 117(1):86-95.

49. Zhao JJ, Lin J, Yang H, Kong W, He L, Ma X, Coppola D, Cheng JQ: MicroRNA-221/222 negatively regulates estrogen receptor alpha and is associated with tamoxifen resistance in breast cancer. J Biol Chem 2008, 283(45):31079-31086.

50. Di Leva G, Gasparini P, Piovan C, Ngankeu A, Garofalo M, Taccioli C, lorio MV, Li M, Volinia S, Alder H, Nakamura T, Nuovo G, Liu Y, Nephew KP, Croce CM: MicroRNA cluster 221-222 and estrogen receptor alpha interactions in breast cancer. J Natl Cancer Inst 2010, 102(10):706-721.

doi:10.1186/1471-2407-14-426

Cite this article as: Wong et al: Celecoxib increases miR-222 while deterring aromatase-expressing breast tumor growth in mice.

BMC Cancer 2014 14:426.

\section{Submit your next manuscript to BioMed Central and take full advantage of:}

- Convenient online submission

- Thorough peer review

- No space constraints or color figure charges

- Immediate publication on acceptance

- Inclusion in PubMed, CAS, Scopus and Google Scholar

- Research which is freely available for redistribution 